\begin{tabular}{cc|c}
\hline Tar. Bil. Der. & Tarım Bilimleri Dergisi & Journal of Agricultural Sciences \\
& $\begin{array}{c}\text { Dergi web sayfası: } \\
\text { www.agri.ankara.edu.tr/dergi }\end{array}$ & Journal homepage: \\
& www.agri.ankara.edu.tr/journal
\end{tabular}

\title{
Antiviral and Antifungal Activity of Biologically Active Recombinant Bouganin Protein from Bougainvillea spectabilis Willd
}

\author{
Abdullah GÜLLER ${ }^{\mathrm{a}}$, Hikmet Murat SIPAHIOĞLU ${ }^{\mathrm{b}}$, Mustafa USTA ${ }^{\mathrm{a}}$, Emre DEMIRER DURAK ${ }^{\mathrm{a}}$ \\ ${ }^{a}$ Van Yuzuncu Yil University, Faculty of Agriculture, Department of Plant Protection, Van, TURKEY \\ ${ }^{b}$ Inonu University, Faculty of Agriculture, Department of Plant Protection, Malatya, TURKEY
}

\section{ARTICLE INFO}

Research Article DOI: 10.15832/ankutbd.446442

Corresponding Author: Hikmet Murat SİPAHİOĞLU, E-mail: murat.sipahioglu@inonu.edu.tr, Tel: +90 (422) 8461225 Received: 25 November 2016, Received in Revised Form: 05 March 2017, Accepted: 30 March 2017

\begin{abstract}
Bouganin antiviral protein (BAP) gene, one of the ribosome inactivating proteins, isolated from Bougainvillea spectabilis Willd. was cloned, expressed and the antiviral and antifungal activities were investigated. The full-length bouganin antiviral protein gene was amplified by reverse transcription-PCR using mRNA as template extracted from mature leaves. The coding region of bouganin gene was cloned into prokaryotic expression vector pETDuet-1 after amplification with end to end gene specific primers. The recombinant plasmid was transformed into Escherichia coli cells BL21(DE3)pLysS and the expression of BAP gene was induced by isopropyl $\beta$-D thiogalactopyranoside (IPTG). Bouganin antiviral protein having a molecular mass of $28 \mathrm{kDa}$ has been isolated from transformed bacterial colonies. Antiviral activity of bouganin was assayed against Zucchini yellow mosaic virus (ZYMV) by a mechanical inoculation test. The antifungal activity of purified recombinant protein was tested against pathogenic and non-pathogenic Rhizoctonia solani, Trichoderma harzianum, and Fusarium oxysporum fungi using disc diffusion method. The increased amount of antiviral protein reduced the disease severity caused by ZYMV. The bouganin antiviral protein was inhibited the growth of $R$. solani by $30.7 \%$ and of $T$. harzianum by $20 \%$ after $72 \mathrm{~h}$ compared to control. No growth inhibition was observed for F. oxyporum. All plants including controls treated with in vitro expressed BAP protein exhibited severe growth reduction compared with negative control (not treated) plants.

Keywords: Bougainvillea spectabilis; Antimicrobial protein; BAP gene; Expression; Antiviral and antifungal activities
\end{abstract}

\section{Bougainvillea spectabilis Willd. Bitkisinin Biyolojik Olarak Aktif Rekombinant Bouganin Proteininin Antiviral ve Antifungal Aktivitesi}

\section{ESER BILLİSI}

Araştırma Makalesi

Sorumlu Yazar: Hikmet Murat SIPAHİĞLU, E-posta: murat.sipahioglu@inonu.edu.tr, Tel: +90 (422) 8461225 Geliş Tarihi: 25 Kasım 2016, Düzeltmelerin Gelişi: 05 Mart 2017, Kabul: 30 Mart 2017

\section{ÖZET}

Bougainvillea spectabilis Willd. bitkisinden ribozom inaktive eden proteinlerden olan Bouganin antiviral protein (BAP) geni izole edilerek klonlanmış, ifade edilmiş, antiviral ve antifungal özellikleri araştırılmıştır. Bouganin proteinini 
kodlayan genin tamamı bitkinin olgun yapraklarından ekstrakte edilen mRNA'dan Reverse Transkripsiyon-PCR yöntemi ile çoğaltılmıştır. Gen, uçtan uca bölgeyi kapsayacak şekilde tasarlanan spesifik primerler yardımı ile prokaryotik ekspresyon vektörü pETDuet-1'de klonlanmıştır. BAP geninin ifadesi rekombinant plazmitin Escherichia coli (BL21(DE3)pLysS) hücrelerine transferi sonrası isopropyl $\beta$-D thiogalactopyranoside (IPTG) ile teşvik edilmiştir. Molekül ağırlığ 1 yaklaşı $28 \mathrm{kDa}$ olan BAP transforme edilmiş bakterilerden izole edilmiştir. BAP '1n antiviral aktivitesi Zucchini yellow mosaic virus (ZYMV) kullanılarak mekanik inokulasyon yöntemi ile araştırılmıştır. Antifungal aktivitenin belirlenmesi disk difüzyon metodu yardımıyla patojen ve patojen olmayan Rhizoctonia solani, Trichoderma harzianum ve Fusarium oxysporum fungusları ile araştırılmıştır. BAP uygulama miktarı arttıkça ZYMV'nin neden olduğu hastalık şiddetinin azaldığ gelişimini \% 30.7, Trichoderma harzianum'unun gelişimini ise \% 20 oranında inhibe etmiştir. Fusarium oxysporum'un gelişiminde herhangi bir inhibisyon etkisi gözlenmemiştir. In vitro'da ifade edilen BAP proteininin uygulandığı tüm bitkiler (sadece BAP protieni uygulanan kontrol grubu da dahil) uygulama yapılmayan bitkilere oranla şiddetli gelişme geriliği sergilemiştir.

Anahtar Kelimeler: Bougainvillea spectabilis; Antimikrobiyal protein; BAP geni; Ekspresyon; Antiviral ve antifungal aktivite

(C) Ankara Üniversitesi Ziraat Fakültesi

\section{Introduction}

In nature, many plants contain proteins with antiviral activity (Barbieri et al 1993). Antiviral proteins (AVPs) are unable to bind the elongation factors. This leads to the interruption of protein translation step and then, it directly inhibits the protein synthesis on ribosomes (Bolognesi et al 2000; Qi et al 2004). Ribosome-inactivating proteins (RIPs) possess sitespecific RNA N-glycosidase activity catalyzing the removal of a single adenine base from a conserved loop of the 28S rRNA of eukaryotic ribosomes (Endo et al 1987) and the 23S rRNA of prokaryotic ribosomes (Hartley et al 1991). Some of these AVPs are belong to the family of RIPs (Barbieri et al 1993).

RIPs have been reported in fungi, bacteria, plants, and algae (Girbés et al 2004). RIPs are common among the plants and generally found in families, such as Poaceae, Euphorbiaceae, Cucurbitaceae, and particularly to Caryophyllales superorder (Grasso \& Shepherd 1978; Stirpe et al 1983; Stirpe \& Barbieri 1986; Kwon et al 2000). In plants, the presence of the RIPs has been reported to occur in leaves, roots, seeds, and tubers in different concentrations (Stirpe et al 1992).

Based on their functions and structures, the RIPs are commonly classified into two subgroups. Type I proteins, which their molecular masses ranges between 28 and $35 \mathrm{kDa}$, consist a single polypeptide chain (Stirpe et al 1983). Type II proteins, which is linked to a cell-binding B chain, consist of a catalytically active A chain (Barbieri \& Stirpe 1982; Stirpe et al 1992).

AVPs have been the focus of many researches because of their selective toxicity function. Therefore, enzymatic activities of RIPs have been used; in plant defence (Logemann et al 1992; Lodge et al 1993; Madin et al 2000), AIDS (Scadden et al 1998; Donayre Torres et al 2009), therapeutics against tumors (Schnell et al 1996; Wang et al 1998a), anti-fungal activities (Wang et al 1998b) and even biological weapon (Weiner 1996; Christopher et al 1997). RIPs have also been reported to antiviral (Sadasivam et al 1991) and antibacterial (Hakuba et al 1991; Hartley et al 1991) properties.

Bougainvillea spectabilis Willd. is an ornamental plant belonging to Nyctaginaceae family and commonly known Bougainvillea or Great Bougainvillea (Kobayashi et al 2007). A ribosome inactivating protein gene, bouganin, has been isolated from B. spectabilis. Based on SDS/ PAGE analysis, the molecular mass of single-chain bouganin is estimated approx. $29 \mathrm{kDa}$ (Bolognesi et al 1997). With the present study, we targeted to clone and express the RIP gene from Bougainvillea and test antiviral and antifungal activities by constructing the prokaryotic expression plasmid 
encoding BAP gene. The inhibitory effects of the recombinant BAP was documented.

\section{Material and Methods}

\subsection{Plant material}

Bougainvillea (B. spectabilis) plant obtained from western part of Turkey was grown in a growth chamber at Van Yuzuncu Yil University Department of Plant Protection. Seeds of squash (Cucurbita pepo L.) plant were obtained from the regional certified resources and the seedlings were grown in pots containing sterile torf. All plants were grown at $26{ }^{\circ} \mathrm{C}$ with a $16 \mathrm{~h} / 8 \mathrm{~h}$ light/dark period.

\subsection{Test microorganisms}

A highly virulent strain of ZYMV was used to test antiviral activities. The virus isolate was maintained on squash (Cucurbita pepo L.) seedlings in climate chamber. Viral inoculum was prepared in sodium phosphate buffer $(0.01 \mathrm{M}, \mathrm{pH}$ 7.2) from systematically infected leaves of $C$. pepo. Three fungal isolates, Fusarium oxysporum (pathogen), Rhizoctonia solani (pathogen) and Trichoderma harzianum (non-pathogen) were used to test for the antifungal assays. The fungal isolates were cultured and maintained on potato dextrose agar (DIFCO, USA) and kept at the temperature of $25^{\circ} \mathrm{C}$. All viral and fungal isolates used in this study were supplied from the Department of Plant Protection of Van Yuzuncu Yil University.

\subsection{Isolation and molecular cloning of a full-length BAP gene}

The extraction of mRNA was made from the mature leaves of $B$. spectabilis with silica-based method (Foissac et al 2001). Reverse transcription was carried out using a commercial kit (RevertAid First Strand cDNA kit, Vilnius, Thermo-FermantasLithuania). The complete bouganin gene was isolated by PCR amplification. The gene specific primers (B-Bam HI-F-5'-CAGT GGATCCGAT GGGTTGGTGGGCTATCAT-3' and B-SacI-R5'-CAGTGAGCTCTTAGGCAATGTTTGGCT CTAGT-3') were designed for the amplification of full length bouganin gene based on registered sequences in GenBank (GenBank access number AF445416) using Vector NTI Software. The primers contained BamHI and SacI restriction sites and four unrelated nucleotide residues at their 5 'end in order to facilitate the cloning into the pETDuet1vector (Novagen, Darmstadt, Germany). The gene was then sub-cloned into pGEM-T Easy vector (Promega, USA). The following PCR cycle was used to amplify the BAP gene: denaturation at 95 ${ }^{\circ} \mathrm{C}$ for $3 \mathrm{~min}$, followed by 40 cycles of $95^{\circ} \mathrm{C}$ for 1 min, annealing at $50^{\circ} \mathrm{C}$ for $1 \mathrm{~min}$, and an extension of $72{ }^{\circ} \mathrm{C}$ for $1 \mathrm{~min}$, with a final extension of $72{ }^{\circ} \mathrm{C}$ for $10 \mathrm{~min}$. A $50 \mu \mathrm{L}$ of PCR mixture contained; 1 $\mu \mathrm{L}$ of each primer (100 pmol), $1 \mu \mathrm{L}$ of dNTPs $(10$ $\mathrm{mM}$ each), $3 \mu \mathrm{L}$ of $\mathrm{MgCl}_{2}(25 \mathrm{mM}), 2 \mu \mathrm{L}$ of cDNA, $0.4 \mu \mathrm{L}$ of Go Taq G2 Hot Start DNA polymerase, $5 \mu \mathrm{L}$ of $10 \times$ reaction buffer and $36.6 \mu \mathrm{L}$ of DNase free water. The amplified DNA was electrophoresed in $1 \%$ agarose gel. DNA bands were purified using a gel extraction kit (Isolate II PCR and Gel Kit, Bioline, Germany).

\subsection{Construction of vector for inducible expression of BAP gene and the purification of recombinant His-tagged bouganin protein}

BamHI and SacI sites of pETDuet-1, containing 6× His Tag coding sequence, were used to construct the recombinant plasmid. The BAP bearing plasmids were then transformed into competent cells of E. coli BL21(DE3)pLysS cells using a micropulser (BioRad, USA). Luria-Bertani (LB) broth agar containing ampicillin was used to grow transformed cells at $37^{\circ} \mathrm{C}$ overnight. BAP gene bearing clones were determined by colony-PCR, sequence analysis and by restriction endonucleases. One of the sequenced clones was used for further study. Positively identified clone was grown on an LB broth to OD 600 0.6. With a constant shaking at $25^{\circ} \mathrm{C}$ for $16 \mathrm{~h}$, the bacterial growth was stimulated by adding IPTG to a final concentration of $0.4 \mathrm{mM}$. The growth media was centrifuged and the bacterial cells were pelleted and resuspended with proteinase inhibitor (Roche, Germany). After adding $0.5 \mathrm{~mL}$ of TrisHCl (pH 7.5), $1 \mathrm{~mL}$ of NP40 (10\%), 25 $\mu \mathrm{L}$ of $\mathrm{MgCl}_{2}(1 \mathrm{M}), 7 \mu \mathrm{L}$ of 2-mercaptoethanol and 
$20 \mu \mathrm{L}$ of DNase I (10 $\left.\mathrm{U} \mathrm{mL}^{-1}\right)$, the suspension was sonicated four times (3-5 s) in ice, then, the mixture was incubated at $4{ }^{\circ} \mathrm{C}$ for $45 \mathrm{~min}$ on a shaker. After adding $0.3 \mathrm{~g}$ of $\mathrm{NaCl}$ (final concentration $0.5 \mathrm{M}$ ) the protein extract was ultracentrifuged at $30,000 \mathrm{rpm}$ for $30 \min \left(4^{\circ} \mathrm{C}\right)$. Recombinant His-tagged BAP protein was purified by chromatography on a Ni2+-NTA agarose resin column. After washing the column with TL buffer (2.5 mL 1M Tris-HCl pH 7.5, $1.46 \mathrm{~g} \mathrm{NaCl}$,

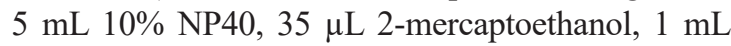
$1 \mathrm{M}$ imidazole $\mathrm{pH} 8.0)$ BAP protein was eluted with TE buffer ( $50 \%$ of imidazole and $50 \%$ of TL buffer). Fraction containing BAP protein was analyzed by $12 \%$ SDS-PAGE electrophoresis gel along with molecular weight markers (Laemmli 1970; Sankian et al 2007). The protein concentrations were determined according to the method of Bradford (Bradford 1976)

\subsection{Bioassay of BAP protein for antiviral activity}

The purified BAP protein was suspended in $10 \%$ DMSO at final concentrations of 2, 4 and $8 \mu \mathrm{L}$ and used as stock solutions and applied to squash cotyledons by using a sterile pipette tip periodically through 4 days. Then, for each treatment, ZYMV extract $(100 \mu \mathrm{L})$ was inoculated on squash cotyledons (Schmitt et al 2001). The development of symptoms was observed for three weeks and the symptoms were recorded as scale value. The controls were consisted of "only BAP protein", "only DMSO 10\%", "only elution buffer (TE) (50\% imidazole pH $8.0+50 \%$ TL buffer)", "only ZYMV", and 10\% DMSO+Elution buffer. No treated plants were also used as controls (Table 1). For each treatment, the cotyledons of three $C$. pepo plants were used. All of them were tested in three replicates in each run of the experiments.

Antiviral activity of BAP protein was measured by a disease severity index (DSI) assay using C. pepo cotyledons and Zucchini yellow mosaic virus (ZYMV). A 0 to 5 rating scale was adapted to score the disease severity index (DSI) described by Liu et al (1995), where $0=$ no symptoms, $1=$ leaf spotting at least fifty percent of the leaf surface area, $2=$ leaf spotting at least more than fifty percent of leaf surface area, $3=$ mottle and mosaics, $4=$
Table 1- The groups created for determination of antiviral activity of bouganin protein and control groups

\begin{tabular}{cl}
\hline Groups & Treatments \\
\hline 1 & $10 \% \mathrm{DMSO}+2 \mu \mathrm{L} \mathrm{BAP}$ \\
2 & $10 \% \mathrm{DMSO}+4 \mu \mathrm{L} \mathrm{BAP}$ \\
3 & $10 \% \mathrm{DMSO}+8 \mu \mathrm{L} \mathrm{BAP}$ \\
4 & $10 \% \mathrm{DMSO}+2 \mu \mathrm{L} \mathrm{BAP}+\mathrm{ZYMV}$ \\
5 & $10 \% \mathrm{DMSO}+4 \mu \mathrm{L} \mathrm{BAP}+\mathrm{ZYMV}$ \\
6 & $10 \% \mathrm{DMSO}+8 \mu \mathrm{L} \mathrm{BAP}+\mathrm{ZYMV}$ \\
7 & Only ZYMV (PC) \\
8 & No treatment $\mathrm{NC})$ \\
9 & Only $10 \% \mathrm{DMSO}$ \\
10 & Only TE \\
11 & $10 \% \mathrm{DMSO}+\mathrm{TE}$ \\
\hline
\end{tabular}

severe mottle, mosaics and leaf deformations, $5=$ severe disease symptoms on leaf surface including shoestring symptom. DSI was calculated based on the Equation 1.

Disease severity index $(\mathrm{DSI})=\Sigma(A \mathrm{x} B) /(T \times D) \times 100$

Where; $A$, scale number; $B$, number of symptomatic leaves; $T$, total number of leaves; $D$, highest scale.

Statistical significance of the treated groups mean with that of control groups were analyzed by SAS 9.4 (SAS 2014) package program. The General Linear Model analysis was used to determine the differences between the groups in the study followed by Duncan's multiple range tests to separate means. Differences were considered statistically significant if $\mathrm{P}<0.05$. To determine the presence of $\mathrm{ZYMV}$, inoculated squash groups were tested by RT-PCR as described by Özer et al (2012). Before inoculation, the plants were exposed to recombinant BAP protein for 4 days and were kept in a growth chamber for 3 weeks. After BAP application, the squash plants were inoculated with ZYMV in the cotyledon leaf stage. The plants were then scored for ZYMVinduced symptom severity. The presence of viral RNA in the inoculated plants was tested by RT-PCR and fresh and dry weights of plants were measured. 


\subsection{Antifungal activity of BAP protein}

The antifungal activity of BAP was tested in vitro by a radial growth inhibition as described by Schlumbaum et al (1986). The test was conducted using sterile $9 \mathrm{~cm}$ diameter petri dishes. Mycelial plugs ( $5 \mathrm{~mm}$ in diameter) were placed on to $2 \mathrm{~cm}$ aside from the outermost of each plate. A total of $50 \mu \mathrm{L}$ filter sterilized antiviral protein and TE buffer was loaded onto the filter paper disks. As a group of control, different petri dishes were prepared for each fungus. The plates were incubated at $25{ }^{\circ} \mathrm{C}$ for 7 days for which the hyphae grew to outwards from the center. The inhibition effect was observed daily following the treatment (24, 48 and $72 \mathrm{~h}$ ). The fungal growth was measured $(\mathrm{mm})$ daily and percentage inhibition in growth calculated. Three replicates were formed for each fungus.

\section{Results}

\subsection{Cloning and expression of the bouganin gene}

The RT-PCR result revealed that only one specific DNA band, 893 bp in length, was visualized in agarose gel electrophoresis. After cloning in expression vector, the gene was sub-cloned in pGEM-T Easy vector. The purified recombinant plasmids were then sequenced bidirectionally to verify the authenticity of the amplicon. The sequencing report showed that the BAP gene shared $85 \%$ identity with other isoforms of BAP sequences from Bougainvillae species. The BAP gene has an initiation amino acid methionin (ATG), and terminated by alanin amino acid (GCC). The BAP gene contained a complete open reading frame and had no introns. The sequence obtained in this study has been assigned the GenBank with the accession no. KP096226.

\subsection{SDS-PAGE analaysis of expressed and purified recombianant His-tagged bouganin protein}

After the recombinant plasmid containing an N-Terminal 6× Histidin Tag sequence was transformed into the bacterial cells, the fused HisBAP protein was purified by utilizing Ni-NTA affinity column. Based on SDS-PAGE analysis it was shown that the BAP gene was expressed after
IPTG induction. As expected, a $28 \mathrm{kDa}$ fused BAP protein was observed. A very slight unrelated protein bands were seen on SDS-PAGE gel (Figure 1). The concentration of the purified His-tagged bouganin protein was determined as $46.8 \mu \mathrm{g} \mathrm{mL}^{-1}$.

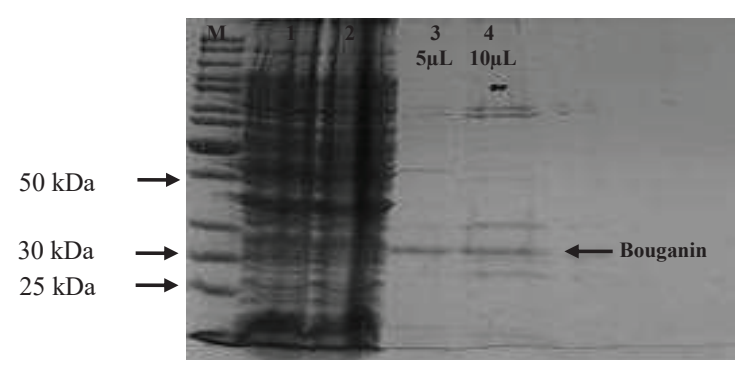

Figure 1- 12\% SDS-PAGE electrophoresis gel analysis of the bouganin protein; 1 , protein profile of IPTG-inducted $E$. coli containing recombinant plasmids; 2, protein profile of IPTG uninducted $E$. coli bacteria containing the recombinant plasmid; 3 and 4, purified bouganin protein profile; $M$, molecular protein size marker

\subsection{Antiviral activity of BAP protein}

The antiviral activity of recombinant BAP protein was examined by symptom expression on $C$. pepo. The results showed that the disease severity index (DSI) was $68.2 \%, 61.4 \%$ and $58.7 \%$ with the application of 2,4 and $8 \mu \mathrm{L}$ of purified BAP, respectively. The DSI of positive control (PC) was recorded as $72.9 \%$. The most active amount was determined as 8 microliter of BAP protein, which exhibited a DSI of $58.7 \%$. However, by using local lesion analysis Choudhary et al (2008) reported a high level of inhibition ( $94 \%)$ against Tobacco mosaic virus (TMV). Our results demonstrate that the inhibitory activities of BAP against ZYMV are positively correlated with the amount. Therefore, the inhibition of infection and symptom expression by BAP were dose dependent between 2 and $8 \mu \mathrm{L}$ (Figure 2).

Furthermore, pretreatment of squash leaves with BAP protein for four days before inoculation with ZYMV did not prevent the virus infection. All tested uninoculated squash leaves (controls) were negative while the all inoculated squash leaves 
(a)

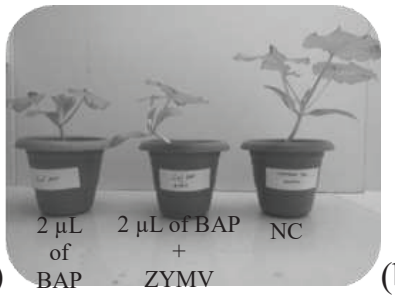

(b)

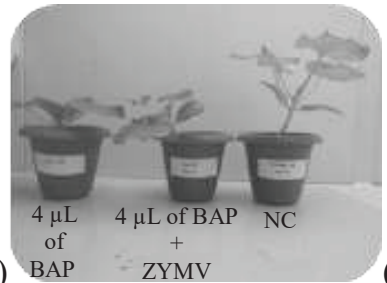

(c)

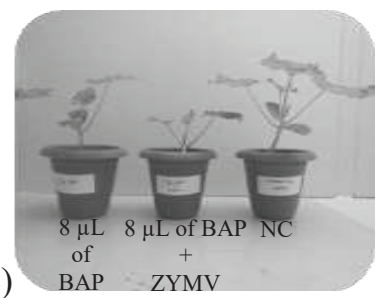

Figure 2- Experiment of bouganin antiviral protein (BAP) activity to Zucchini yellow mosaic virus (ZYMV); the cotyledon leaves were pretreated with 2,4 and $8 \mu \mathrm{L}$ of BAP in the presence of $10 \%$ DMSO for four days then, $100 \mu \mathrm{L}$ of $\mathrm{ZYMV}$ inoculum were inoculated to the same leaves; the only purified BAP of 2,4 , and $8 \mu \mathrm{L}$ were also kept as controls in the presence of $10 \%$ DMSO; NC, negative control

were reacted positive in RT-PCR tests 3 weeks after inoculation. DSI analysis of inoculated squash plants demonstrated that plants treated with $4 \mu \mathrm{L}$ and $8 \mu \mathrm{L}$ of BAP showed a significant reduction $(\mathrm{P}<0.05)$ in symptom expression compared with controls.

When BAP was applied with $10 \%$ DMSO to the leaves of squash plants, a severe reduction $(50 \%$ or greater) occurred in plant size. The controls involving "only $10 \%$ DMSO", "only TE", and "only $10 \%$ DMSO+TE" showed no significant changes in plant size as compared to the control group (NC). Fresh and dry weights of BAP treated squash plants were also showed a severe decrease as compared to control plants. The obtained data was evaluated with the standard deviations and found significant statistically (Table 2). These results suggest that BAP protein blocks essential cellular functions needed for growth. The reduction was greater when ZYMV was inoculated after BAP treatment period. In those plants, besides delayed symptom expression as compared with positive controls, a severe growth reduction was also recorded.

\subsection{Antifungal activity of BAP protein}

The results of antifungal activity of BAP against various fungi $[F$. oxysporum (pathogen), $R$. solani (pathogen), and a non-pathogenic fungus $T$. harzianum, (data not shown)] are shown in Figure 3. For the determination of antifungal activity, a $50 \mu \mathrm{L}$ (46.8 $\mu \mathrm{g} \mathrm{mL}^{-1}$ in $1 \mathrm{mM}$ TE buffer, $\mathrm{pH}$ 7.5) of filter sterilized BAP suspension was used. It was shown that BAP inhibited the two of these fungi (Table 3).
Table 2- Average fresh and dry weights and statistical analysis of the squash plants used in this study

\begin{tabular}{|c|c|c|}
\hline Groups $^{1}$ & $\begin{array}{l}\text { Dry weight (g) } \\
\left(\bar{X} \pm S_{\bar{x}}\right)^{2}\end{array}$ & $\begin{array}{l}\text { Fresh weight (g) } \\
\qquad\left(\bar{X} \pm S_{\bar{x}}\right)\end{array}$ \\
\hline $\mathrm{NC}$ & $4.54 \pm 0.12^{\mathrm{a}}$ & $21.40 \pm 0.34^{\mathrm{a}}$ \\
\hline Only ZYMV (PC) & $3.87 \pm 0.08^{\mathrm{b}}$ & $14.40 \pm 0.23^{\mathrm{b}}$ \\
\hline Only TE & $4.60 \pm 0.03^{\mathrm{a}}$ & $21.30 \pm 0.21^{\mathrm{a}}$ \\
\hline Only DMSO $10 \%$ & $4.60 \pm 0.20^{\mathrm{a}}$ & $21.20 \pm 0.50^{\mathrm{a}}$ \\
\hline TE+DMSO & $4.70 \pm 0.10^{\mathrm{a}}$ & $21.70 \pm 0.14^{\mathrm{a}}$ \\
\hline $2 \mu \mathrm{L}$ BAP & $3.90 \pm 0.11^{\mathrm{b}}$ & $15.33 \pm 0.35^{\mathrm{b}}$ \\
\hline $4 \mu \mathrm{L} \mathrm{BAP}$ & $3.61 \pm 0.24^{\mathrm{bc}}$ & $14.56 \pm 0.34^{\mathrm{b}}$ \\
\hline $8 \mu \mathrm{L}$ BAP & $3.40 \pm 0.09^{c}$ & $13.81 \pm 0.79^{\mathrm{b}}$ \\
\hline $2 \mu \mathrm{L}$ BAP+ZYMV & $3.72 \pm 0.05^{\mathrm{bc}}$ & $11.17 \pm 0.85^{\mathrm{c}}$ \\
\hline $4 \mu \mathrm{L}$ BAP+ZYMV & $3.64 \pm 0.12^{\mathrm{bc}}$ & $10.47 \pm 1.43^{\mathrm{c}}$ \\
\hline $8 \mu \mathrm{L}$ BAP $+Z \mathrm{YMV}$ & $3.55 \pm 0.12^{\mathrm{bc}}$ & $7.83 \pm 1.50^{\mathrm{d}}$ \\
\hline
\end{tabular}

${ }^{1}$; $\mathrm{a}, \mathrm{b}, \mathrm{c}, \mathrm{d}$ means the difference between the averages with different letters in the same column is significant; ${ }^{2}$, mean \pm standard error of mean; BAP, Bouganin antiviral protein; DMSO, dimethylsulphoxide; ZYMV, Zucchini yellow mosaic virus; TE, Tris EDTAbuffer; PC, positive control; NC, no treatment

Based on time course experiment a moderate mycelia growth inhibition was observed with $50 \mu \mathrm{L}$ purified BAP for up to $72 \mathrm{~h}$ of incubation. Two fungi $R$. solani and T. harzianum, exhibited a crescent-shaped zone of inhibition at their mycelial front (Figure 3). BAP was found to be most active on these two. No antifungal activity was detected against mycelial growth of F. oxyporum. TE buffer which was used as negative control did not showed any impact on the growth of fungi. Another remarkable finding in this study that bouganin protein was promoted the sporulation of T. harzianum (Figure 4). 
(a)

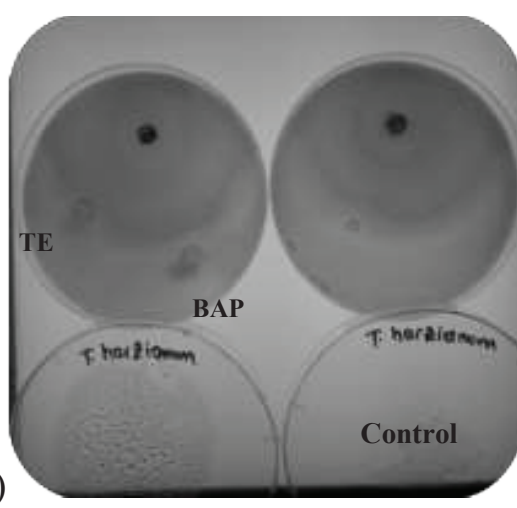

(b)

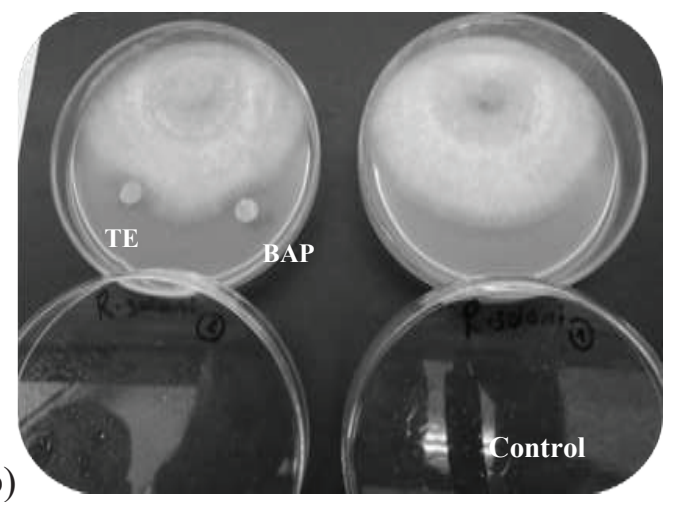

Figure 3- Antifungal activity of BAP against T. harzianum (a) and $R$. solani experiment (b); the dosage of the antiviral protein was $46.8 \mu \mathrm{g} \mathrm{mL}^{-1}$; a crescent-shaped zone of inhibition at the mycelial front is seen; the controls consisted of $1 \mathrm{mM}$ TE buffer, pH 7.5 and untreated separate inoculations of same fungi

Table 3- Inhibitory effect of Bouganin antiviral protein against some fungi in PDA

\begin{tabular}{|c|c|c|c|c|c|}
\hline \multirow[t]{2}{*}{ Fungal agent } & & \multicolumn{3}{|c|}{$\begin{array}{l}\text { The average growth of the fungus } \\
\text { mycelium }(\mathrm{cm})\end{array}$} & \multirow{2}{*}{$\begin{array}{l}\text { Inhibition } \\
(\%)\end{array}$} \\
\hline & & $24 h$ & $48 h$ & $72 h$ & \\
\hline F. oxysporum & $\begin{array}{l}\text { Control } \\
\text { Treatment }\end{array}$ & - & $\begin{array}{l}1.9 \\
1.6\end{array}$ & $\begin{array}{l}2.9 \\
2.9\end{array}$ & - \\
\hline R. solani & $\begin{array}{l}\text { Control } \\
\text { Treatment }\end{array}$ & $\begin{array}{l}3.7 \\
3.3\end{array}$ & $\begin{array}{l}5.9 \\
4.3\end{array}$ & $\begin{array}{l}6.5 \\
4.5\end{array}$ & 30.7 \\
\hline T. harzianum & $\begin{array}{l}\text { Control } \\
\text { Treatment }\end{array}$ & $\begin{array}{l}2.8 \\
2.3\end{array}$ & $\begin{array}{l}3.7 \\
3.7\end{array}$ & $\begin{array}{l}5 \\
4\end{array}$ & 20 \\
\hline
\end{tabular}

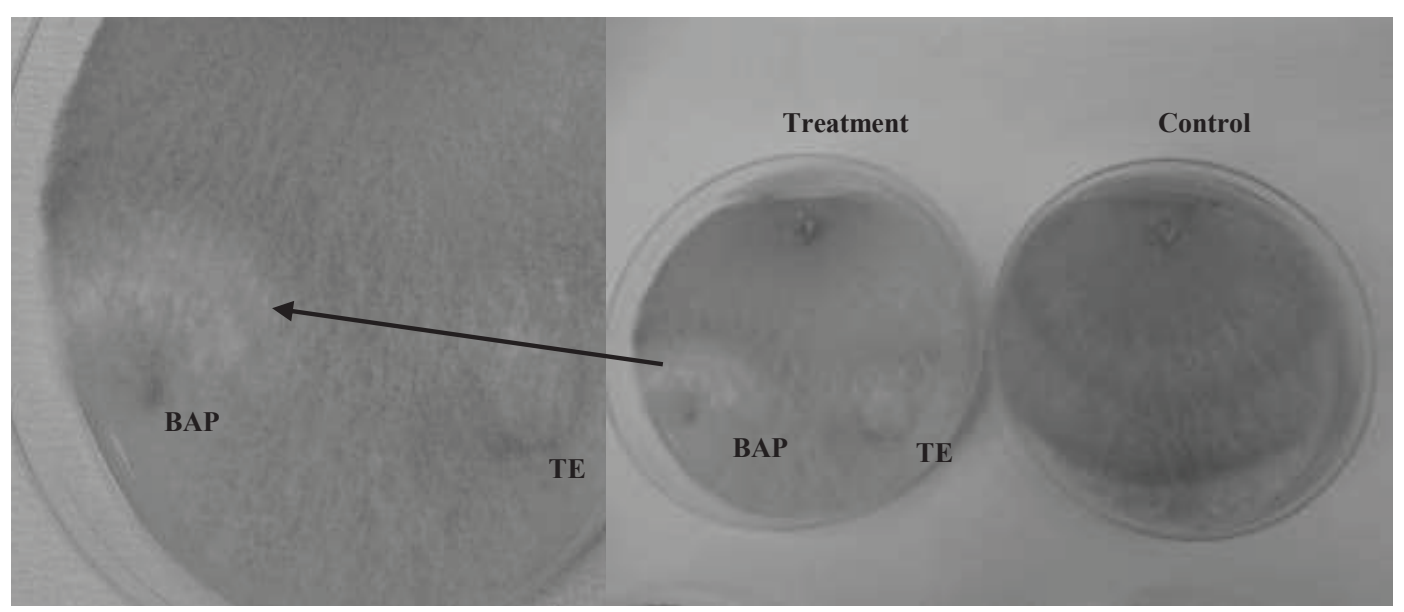

Figure 4- Sporulation of T. harzianum at the point where the fungus encounters with BAP protein

Tarım Bilimleri Dergisi - Journal of Agricultural Sciences $\quad \mathbf{2 4}$ (2018) 227-237 


\section{Discussion}

The BAP I gene contains 297 amino acids, phylogenetic analysis of BAP I nucleotide sequence with those of other BAPs, on a consensus length of 893 nucleotide residues, established a maximum homology of $85 \%$.

The in vitro tests showed that BAP proteins had activities against ZYMV symptom reduction, but its inhibitory activity on ZYMV infection was not confirmed. The relationship between the concentration of BAP protein and its antiviral activity toward tested virus was not established in this investigation. However, here we report that the inhibitory activity of BAP protein against ZYMV is a dose dependent manner. There was a steady decrease in the DSI with the increase in the amount of BAP for all the replicates tested for ZYMV. The present findings suggest that the antiviral activity of BAP could be related to its amount in diffused cells. It has been reported that the all types of RIPs have antiviral activity against plant viruses (Stevens et al 1981; Hartley et al 1996; Jackman et al 1999). Most of the studies shows that inhibit the symptoms of the virus but the presence or the absence of the virus have not been studied. Although disease severity has been decreased and is also important statically $(\mathrm{P}<0.05)$, when BAP protein applied to cotyledons of squash plants did not prevent the virus entry and it did not stop the ZYMV infection. BAP protein exhibits strong antiviral activity particularly toward Tobacco mosaic virus (Choudhary et al 2008). BBAP1 protein which derived from another Bougainvillea species (B. xbuttiana) is similar with the effect of inhibition showed against Sunnhemp rosette virus (SRV) (Choudhary et al 2007).

Antifungal activities of BAP protein have been performed using radial growth inhibition assay in R. solani, T. harzianum and F. oxyporum. This protein displayed an inhibitory activity on $R$. solani, and $T$. harzianum, but there was no obvious inhibitory effect against $F$. oxyporum. In our study, the bouganin protein has inhibited the development of $R$. solani $(30.7 \%)$ and T. harzianum (20\%) mycelium. BAP protein has not shown any positive or negative effect in F. oxyporum. These findings have shown similarity with the results obtained from the studies carried out of Lodha et al (2010) by BBAP1 (Bougainvillea xbuttiana antiviral protein). In parallel, the BAP protein derived from $B$. spectabilis plant has inhibited mycelial growth of the Sclerotium rolfsii which is a plant pathogen and determined to reduce the growth in 3 days (Abbas 2007). In other study, conducted by Barbieri et al (2006), the RIP gene isolated from Cucurbita moschata plant inhibited the growth of two strain of Phytophthora infestans. Roberts \& Selitrennikoff (1986) reported that the barley RIP inhibited Trichoderma reesei growth on agar plates. Besides, the abundant maize kernel ribosome-inactivating protein (RIP1) has been shown to have antifungal activity against Aspergillus nidulans (Nielsen et al 2001). In our trials, the BAP antiviral protein has encouraged sporulation of $T$. harzianum.

Interestingly, we have found a unique characteristic of BAP protein that distinguishes it from known types of RIPs. We found that the BAP treatment along with $10 \%$ DMSO causes a severe size reduction in squash. It has been hypothesized that once the BAP reaches the plant cells, it may depurinate the host plant ribosomes and arrests the protein synthesis necessary for the growth. In eukaryotes, it has been well documented that the ribosome inactivating trait of RIPs is responsible for inhibition of protein synthesis (Gessner \& Irvin 1980; Irvin 1995). To date, the potential size reduction effect of RIPs in plants has not been investigated. To our knowledge, this is the first time that plant size reduction activity has been reported for BAP protein which has been grouped among type I RIPs. The RIPs are known to have the ability to inactivate fungal, bacterial, mammalian and plant ribosomes (Girbés et al 2004). RIPs act on ribosomes to inhibit polypeptide chain elongation (Olsnes \& Pihl 1980; Barbieri \& Stirpe 1982; Irvin 1983) and thereby arresting protein synthesis and causing cell death (Endo \& Tsurugi 1988). For better understanding of the molecular mechanisms of BAP blockage of cellular functions that are needed for growth, would be the focus in the future research. 
With the present study, we cloned and expressed the RIP gene from Bougainvillea and tested antiviral and antifungal activities by constructing the prokaryotic expression plasmid encoding BAP gene. Here, we describe the isolation and properties of BAP antiviral protein with a molecular mass of 28 $\mathrm{kDa}$ from B. spectabilis. Full-length DNA encoding bouganin antiviral protein gene was generated using gene specific forward and reverse primers and cloned into pETDuet-1 expression vector. In conclusion, purified E. coli-expressed BAP antiviral protein from $B$. spectabilis has multifunctional activity against ZYMV, $R$. solani, and $T$. harzianum. This is the first report of the plant growth reduction effect of BAP.

\section{Acknowledgements}

This research was financially supported by the Research Fund of University of Van Yuzuncu Yil (YYU-BAP, Project no: 2013-FBE-D012).

\section{References}

Abbas S (2007). Cloning and expression of cDNA encoding ribosome inactivating proteins. MSc Thesis, Dharwad University (Unpublished), India

Barbieri L \& Stirpe F (1982). Ribosome-inactivating proteins from plants: Properties and possible uses. Cancer Survey 1: 489-520

Barbieri L, Battelli M G \& Stirpe F (1993). Ribosome inactivating proteins from plants. Biochimica et Biophysica Acta 1154: 237-282

Barbieri L, Polito L, Bolognesi A, Ciani M, Pelosi E, Farini V, Jha A K, Sharma N, Vivanco J M, Chambery A, Parente A \& Stirpe F (2006). Ribosomeinactivating proteins in edible plants and purification and characterization of a new ribosome-inactivating protein from Cucurbita moschata. Biochimica et Biophysica Acta 1760: 783-792

Bolognesi A, Polito L, Olivieri F, Valbonesi P, Barbieri L, Giulia Battelli M, Vittoria Carusi M, Benvenuto E, Del Vecchio Blanco F, Di Maro A, Parente A, Di Loreto M \& Stirpe F (1997). New ribosome inactivating proteins with polynucleotide: adenosine glycosidase and antiviral activities from Basella rubra L. and Bougainvillea spectabilis Willd. Planta 203: 422-429
Bolognesi A, Polito L, Tazzari P L, Lemoli R M, Lubelli C, Fogli M, Boon L, de Boer M \& Stirpe F (2000). In vitro anti-tumour activity of anti-CD80 and antiCD86 immunotoxins containing type 1 ribosomeinactivating proteins. British Journal of Haematology 110: $351-361$

Bradford M M (1976). A rapid and sensitive method for the quantitation of microgram quantities of protein utilizing the principle of protein-dye binding. Analytical Biochemistry 72: 248-254

Choudhary N L, Yadav O P \& Lodha M L (2007). Ribonuclease, deoxyribonuclease, and antiviral activity of Escherichia coli-expressed Bougainvillea xbuttiana antiviral protein. Biochemistry (Moscow) 73: 273-277

Choudhary N, Kapoor H C \& Lodha M L (2008). Cloning and expression of antiviral/ribosome-inactivating protein from Bougainvillea xbuttiana. Journal of Biosciences 33: 91-101

Christopher G W, Cieslak T J Z, Pavlin J A \& Eitzen E M $\mathrm{Jr}$ (1997). Biological warfare. A historical perspective. Jama 278: 412-417

Donayre Torres A J, Esquivel Soto E, Gutierrez Xicotencatl M D, Esquivel Guadarrama F R \& Gomez Lim M A (2009). Production and purification of immunologically active core protein p24 from HIV-1 fused to ricin toxin B subunit in E. coli. Journal of Virology 6: 1-11

Endo Y \& Tsurugi K (1988). The RNA N-glycosidase of ricin A chain: The characteristics of enzymatic activity of ricin A chain with ribosomes and rRNA. The Journal of Biological Chemistry 263: 8735-8739

Endo Y, Mitsui K, Motizuki M \& Tsurugi K (1987). The mechanism of action of ricin and related toxic lectins on eukaryotic ribosomes. The site and the characteristics of the modification in $28 \mathrm{~S}$ ribosomal RNA caused by the toxins. Journal of Biological Chemistry 262(12): 5908-5912

Foissac L, Gentit P, Svanetia-Dumas L, Dulucq M J \& Candresse T (2001). Polyvalent detection of fruit tree tricho, capillo, and fovea viruses by nested RT-PCR using degenerated and inosine containing primers (PDO RT-PCR). Acta Horticulturae 550: 37-43

Gessner S L \& Irvin J D (1980). Inhibition of elongation factor2-dependent translocation by the pokeweed antiviral protein and ricin. Journal of Biological Chemistry 255: 3251-3253 
Girbés T, Ferreras J M, Arias F J \& Stirpe F (2004). Description, distribution, activity and phylogenetic relationship of ribosome inactivating proteins in plants, fungi and bacteria. Mini-Reviews in Medicinal Chemistry 4: 461-476

Grasso S \& Shepherd R J (1978). Isolation and partial characterization of virus inhibitors from plant species taxonomically related to Phytolacca. Journal of Physiology Biochemistry 68: 199-205

Hakuba N, Miyano M, Kataoka J \& Noma M (1991). Escherichia coli ribosome is inactivated by Mirabilis antiviral protein which cleaves the N-glikosidic bond at A2660 of 23S ribosomal RNA. Journal of Molecular Biology 221: 737-743

Hartley M R, Legname G, Osborn R, Chen Z \& Lord J M (1991). Single chain ribosome inactivating proteins from plants depurinate Escherichia coli $23 \mathrm{~S}$ ribosomal RNA. FEBS Letters 290(1-2): 65-68

Hartley M R, Chaddock J A \& Bonness M S (1996). The structure and function of ribosome-inactivating proteins. Trends in Plant Science 1: 254-260

Irvin J D (1983). Pokeweed antiviral protein. Pharmacology \& Therapeutics 21: 371-387

Irvin J D (1995). Antiviral proteins from Phytolacca. In: M Chessin, A Zipf \& D DeBorde (Eds), Antiviral Proteins from Higher Plants. CRC Press, Boca Raton, FL pp. 65-69

Jackman M R, Ellis J A, Gray S R, Shurety W \& Luzio J P (1999). Cell polarization is required for ricin sensitivity in a Caco-2 cell line selected for ricin resistance. Biochemistry Journal 341: 323-327

Kobayashi K D, McConnell J \& Griffis J (2007). Bougainvillea. Ornamentals and Flowers 38: 1-12

Kwon S Y, An C S, Liu J R, Kwak S S, Lee H S, Lim J K \& Paek K H (2000). Molecular cloning of a cDNA encoding ribosome-inactivating protein from Amaranthus viridis and its expression in E. coli. Molecules and Cells 10: 8-12

Laemmli U K (1970). Cleavage of structural proteins during the assembly of the head of bacteriophasge T4. Nature 227: 680-685

Liu L, Kloepper J W \& Tuzun S (1995). Introduction of systemic resistance in cucumber against Fusarium wilt by plant growth-promoting rhizobacteria. Phytopathology 85: 695-698

Lodge J K, Kaniewski W K \& Tumer N E (1993). Broad spectrum virus resistance in transgenic plants expressing pokeweed antiviral protein. Proceedings of the National Academy of Sciences of the United Stated of America 90: 7089-7093

Lodha M L, Agarwal S, Biswas K, Vasudev S \& Dubey S C (2010). Antimicrobial activity of native and recombinant antiviral proteins from Bougainvillea xbuttiana leaves against plant pathogenic fungi and viruses. Indian Journal of Agricultural Biochemistry 23: $83-90$

Logemann J, Jach G, Tommerup H, Mundy J \& Schell J (1992). Expression of a barley ribosome-inactivating protein leads to increased fungal protection in transgenic tobacco plants. Biotechnology 10: 305-308

Madin K, Saeasaki T, Ogasawara T \& Endo Y (2000). A highly efficient and robust cell-free protein synthesis system prepared from wheat embryos: Plants apparently contain a suicide system directed at ribosomes. Proceedings of the National Academy of Science of the United Stated of America 97: 559-564

Nielsen K, Payne G A \& Boston R S (2001). Maize ribosome inactivating protein inhibits normal development of Aspergillus nidulans and Aspergillus flavus. Molecular Plant-Microbe Interactions Journal 14: 164-172

Olsnes S \& Pihl A (1980). Toxic lectins and related proteins. In: P H Cohen \& S van Heyningen (Eds), The Molecular Actions of Toxins and Viruses, Elsevier/ North Holland, Amsterdam, pp. 51-106

Özer M, Sipahioğlu H M, Usta M \& Fidan H (2012). Cloning and sequencing of coat protein gene of Zucchini yellow mosaic virus isolated from squash and muskmelon in Turkey. Turkish Journal of Biology 36: 423-429

Qi L, Nett T M, Allen M C, Sha X, Harrison G S, Frederick B A, Crawford E D \& Glode L M (2004). Binding and cytotoxicity of conjugated and recombinant fusion proteins targeted to the gonadotropin-releasing hormone receptor. Cancer Research 64: 2090-2095

Roberts W K \& Selitrennikoff C P (1986). Isolation and characterization of two antifungal proteins from barley. Biochimica et Biophysica Acta 880: 161-170

Sadasivam S, Rajameshewari S \& Jeyarajan R (1991). Inhibition of certain plant viruses by plant extracts. Journal of Ecobiology 3: 53-57

Sankian M, Yousefi M, Pazouki N \& Varasteh A (2007). One-step purification of histidine-tagged profilin with high purity and yield by using metal precipitation. Biotechnology and Applied Biochemistry 47: 185-189 
SAS (2014). SAS/STAT Software: Hangen and Enhanced. SAS, Inst. Inc., Cary, N.C. USA

Scadden D T, Schenkein D P, Bernstein Z, Luskey B, Doweiko J, Tulpule A \& Levine A M (1998). Immunotoxin combined with chemotherapy for patients with AIDS-related nonHodgkin's lymphoma. Cancer 83: 2580-2587

Schlumbaum A, Mauch F, Vogeli U \& Boller T (1986). Plant chitinases are potent inhibitors of fungal growth. Nature 324: 365-367

Schmitt A C, Ravazzolo A P \& Von Poser G L (2001). Investigation of some Hypericum species native to Southern of Brazil for antiviral activity. The Journal of Ethnopharmacology 77: 239-245

Schnell R, Katouzi A A, Linnartz C, Schoen G, Drillich S, Hansmann M L, Schiefer D, Barth S, ZangemeisterWittke U, Stahel R A, Diehl V \& Engert A (1996). Potent anti-tumor effects of an anti-CD24 ricin A-chain immunotoxin in vitro and in a disseminated human Burkitt's lymphoma model in SCID mice. International Journal of Cancer 66: 526-531

Stevens W A, Spurdon C, Onyon L J \& Stirpe F (1981). Effect of inhibitors of protein synthesis from plants on tobacco mosaic virus infection. Experientia 37: 257-259
Stirpe F \& Barbieri L (1986). Ribosome-inactivating proteins up to date. FEBS Letters 195: 1-8

Stirpe F, Gasperi-Campani A, Barnieri L, Falasca A, Abbondanza A \& Stevens W A (1983). Ribosomeinactivating proteins from the seeds of Saponara officinalis L. (soapwort), of Agrostemma githago L. (corn cockle) and of Asparagus officinalis L. (asparagus), and from the latex of Hura crepitans L. (sandbox tree). Biochemical Journal 216: 617-625

Stirpe F, Barbieri L, Battelli M G, Soria M \& Lappi D A (1992). Ribosome-inactivating proteins from plants: present status and future prospects. Biotechnology 10: 405-412

Wang P, Zoubenko O \& Tumer N E (1998a). Reduced toxicity and broad spectrum resistance to viral and fungal infection in transgenic plants expressing pokeweed antiviral protein II. Plant Molecular Biology 38: 957-964

Wang W X, Dong J Y, Zhou S Y, Li W L \& Zhao Y (1998b). Modification of ricin and its hepatotoxicity and activity against hepatocellular cancer in mice. World Journal Gastroenterology 4: 307-310

Weiner S L (1996). Strategies for the prevention of a successful biological warfare aerosol attack. Military Medicine 161: 251-256 